\title{
Ordinal Logistic Regression with an Application to Health Service Quality in Raden Mattaher Jambi Hospital
}

\author{
Feri Tiona Pasaribu ${ }^{1)}$, Ainun Mardia ${ }^{2)}$, Corry Sormin ${ }^{3)}$ \\ Mathematics Department, Fakultas Sains dan Teknologi, Universitas Jambi, \\ Indonesia \\ Email: rieviona@gmail.com; ainun.mardia@unja.ac.id; \\ corry.sormin@unja.ac.id
}

\begin{abstract}
Health care is a treatment received by the community provided by health workers. The quality of health services will provide satisfaction to health services. Service actions that affect the value of satisfaction are availability and completeness of facilities, physical evidence of administration, reliability of officers, responsiveness of officers, guarantees received by patients and families of patients, and empathy felt by patients. This level of satisfaction assessment is in the form of an ordinal scale that is not satisfied, less satisfied, satisfied and very satisfied. The analysis used to determine the level of satisfaction is by ordinal logistic regression analysis. The sample used in this study is the patient or family of patients at Raden Mattaher Hospital. The stages of data analysis used are the validity and reliability test, parameter estimation, model feasibility test, parameter significance test and the best model selection. The results of the analysis obtained the best models $\hat{Y}=\left[1+\exp \left(5,716+2,791 x_{1}+4,064 x_{2}+\right.\right.$ $\left.\left.2,819 x_{4}\right)\right]^{-1}$ and $\quad \hat{Y}=\left[1+\exp \left(12,886+2,791 x_{1}+4,064 x_{2}+\right.\right.$ $\left.\left.2,819 x_{4}\right)\right]^{-1}$ with factors that influence the level of quality of health services at Raden Mattaher Hospital, namely physical evidence, availability and completeness of facilities and responsiveness.
\end{abstract}

Keywords: Service Quality, Ordinal Logistic Regression

\section{Introduction}

Health is a basic need needed by every human being. Health is needed as a base for everyone to live their lives. Particular attention to public health is one of them in health services. Health care is a treatment given by the health stakeholders to the community. According to Muninjaya (2014), this health service always refers to service quality(6). Mulyadi (2013) added that the quality of health services for patients provided by health workers includes empathy, respect and responsiveness to their needs, while the quality of services for health workers is free to do everything professionally(5).

Satisfaction of health services according to Daniel (2010) can be seen in terms of tangible evidence, reliability, responsiveness, assurance and empathy $(2,3)$. This service satisfaction will determine a service quality. This service satisfaction can be categorized into categories of very satisfied, satisfied, less satisfied and dissatisfied. This division of satisfaction categories follows an ordinal data scale. The level of service satisfaction is strongly influenced by several supporting factors, so according to statistics, the possible 35 IEKSAKTA: Berkala IImiah Bidang MIPA 
analysis is ordinal logistic regression analysis. According to Hosmer and Lemeshow (2000) ordinal logistic regression is an analysis that discusses the relationship between predictor variables and response variables that have ordinal data $\operatorname{scales}(2,3)$.

This study will use the object of research, Raden Mattaher Hospital because this hospital has received special attention about health services in Jambi Province, besides that this hospital is a local government hospital which is the hope of the community for better health services. Based on the background above, this study will model the level of quality of public health services at Raden Mattaher Hospital using Ordinal Logistic Regression and look for factors that influence the level of quality of public health services at Raden Mattaher Hospital.

\section{Experimental Section}

Ordinal logistic regression is one of the statistical analyzes to analyze response variables that have an ordinal scale, which consists of two or more categories with predictor variables which can be in the form of categorical or continuous data consisting of two or more variables. The model that can be used for ordinal logistic regression is the logit model. The logit model is the cumulative logit model. This logit model is the ordinal nature of the $\mathrm{Y}$ response formed in cumulative opportunities so that cumulative logit models are models obtained by comparing cumulative opportunities, namely opportunities less than or equal to the category of the $\mathrm{j}$ response at $\mathrm{p}$ predictor variables expressed in vector $\mathrm{X}, \mathrm{P}(\mathrm{Y} \leq \mathrm{j} \mid \mathrm{X})$ with opportunities greater than the response category $-\mathrm{j}, \mathrm{P}(\mathrm{Y}>\mathrm{j} \mid \mathrm{X} \overline{)}(2,3)$. Mathematically it can be written:

$$
P(Y \leq j \mid \bar{X})=\log \left(\frac{P(Y \leq j \mid \bar{X})}{P(Y>j \mid \bar{X})}\right)
$$

Cumulative opportunity, $P(Y \leq j \mid \bar{X})$ is defined:

$P(Y \leq j \mid \bar{X})=\frac{\exp \left(\theta_{j}+\sum_{i=1}^{p} \beta_{i} x_{i}\right)}{1+\exp \left(\theta_{j}+\sum_{i=1}^{p} \beta_{i} x_{i}\right)}$ where $j=1,2, \ldots, J$ is the response category (1).

So that from the cumulative opportunity form a model is obtained where if there are $j$ response categories, the ordinal logistic model formed is:

$\pi_{j}(x)=\frac{1}{1+\exp \left(g_{j-1}(x)\right)}$ with $g_{j-1}(x)=\beta_{0}+\beta_{1} x_{1}+\cdots+\beta_{p} x_{p}$.

The parameters of the ordinal logistic regression model can be estimated using the maximum likelihood method followed by the iterative Weighted Least Square (WLS) method, the Newton-Raphson algorithm.

After estimating the parameters, a test is conducted to find out which predictor variable has a significant effect on the response variable. Simultaneous parameter testing or model feasibility test aims to see if the model used matches the data. The test statistic used is the Likelihood Ratio test defined:

36 IEKSAKTA: Berkala IImiah Bidang MIPA 


$$
G=-2 \log \left[\frac{\prod_{i=1}^{n}\left(\frac{n_{i}}{n}\right)^{n_{i}}}{\prod_{i=1}^{n} \hat{\pi}_{i}^{y_{i}}\left(1-\hat{\pi}_{i}^{y_{i}}\right)^{1-y_{i}}}\right]
$$

The decision criterion $\mathrm{H} \_0$ is rejected if $\mathrm{G}>\chi \chi(\alpha(n-p-1))^{\wedge} 2$ with $n$ many samples and $\mathrm{p}$ many predictor variables, meaning the model matches the data.

After obtaining a model that matches the data, then test the significance of partial parameters. The significance test of the partial parameters is used to test each parameter of the model obtained. If the model used is not suitable for the data, this significance test is not necessary. The test statistics used are the Wald test defined:

$$
W_{i}=\frac{\hat{\beta}_{i}}{\operatorname{SE}\left(\hat{\beta}_{i}\right)}
$$

The decision criterion $\mathrm{H} \_0$ is rejected if $\left|W_{i}\right|>t_{\frac{\alpha}{2}(n-p)}$ with $\mathrm{n}$ lots of samples and $\mathrm{p}$ many predictor variables.

\section{Results and Discussion}

\section{Validity and Reliability}

Previously it will be tested the feasibility of the questionnaire for the data to be taken. 30 samples were chosen which would be tested for the feasibility of the questionnaire. In this study used SPSS 16 software as a tool to test questionnaires that will be used in the study. Based on the value of Extraction, all the factors used have the closeness of the relationship of variables with the factors. This can be shown from the extraction value greater than $50 \%$. This means that the variable has a closeness of the relationship greater than $50 \%$ towards the service quality factor. As for validity, it can be seen from the value of Cronbach's Alpha obtained at 0.766. Because the value of Cronbach's Alpha is greater than $r$ table, all the variables in the questionnaire are valid.

\section{Ordinal Logistic Regression Analysis}

The ordinal logistic equation used in this study to model the level of quality of health services at Raden Mattaher Hospital is defined:
1. $\widehat{Y}=\frac{1}{1+\exp \left(11,995+3,121 x_{1}+4,799 x_{2}+3,203 x_{3}+3,179 x_{4}-0,812 x_{5}+3,301 x_{6}\right)}$
2. $\widehat{Y}=\frac{1}{1+\exp \left(19,946+3,121 x_{1}+4,799 x_{2}+3,203 x_{3}+3,179 x_{4}-0,812 x_{5}+3,301 x_{6}\right)}$

Based on the Model Fitting Information obtained Sig for 0,000 means that the ordinal logistic regression model is suitable for use. Then it will be checked whether each 
variable significantly influences the level of quality of health services. Using the Wald test obtained only the Guarantee variable must be excluded from the model.

\section{Models without Predictor Guarantee Variables}

Analogous to the previous concept, the expected model is obtained as follows:

$$
\begin{aligned}
\text { 1. } & \widehat{Y}=\frac{1}{1+\exp \left(11,905+3,027 x_{1}+4,716 x_{2}+2,9823 x_{3}+2,652 x_{4}+3,239 x_{6}\right)} \\
\text { 2. } \widehat{Y} & =\frac{1}{1+\exp \left(19,774++3,027 x_{1}+4,716 x_{2}+2,9823 x_{3}+2,652 x_{4}+3,239 x_{6}\right)}
\end{aligned}
$$

Based on the Model Fitting Information obtained Sig for 0,000 means that the ordinal logistic regression model is suitable for use. Then check again whether each variable in the new model significantly affects the level of quality of health services. Using the Wald test obtained no parameters to be excluded from the model. But because one of the model requirements is said to be good if all the variables are significant, further testing is needed. This can be seen from the Sig value which is still quite large. Subsequently a similar test will be carried out but by removing the predictor variable Guarantee and Reliability.

\section{Models without Predictor Guaranteed Variables and Reliability}

Analog obtained by the estimation model as follows:

$$
\begin{aligned}
\text { 1. } & \widehat{Y}=\frac{1}{1+\exp \left(9,365+2,523 x_{1}+4,393 x_{2}+3,262 x_{4}+3,448 x_{6}\right)} \\
\text { 2. } \widehat{Y} & =\frac{1}{1+\exp \left(16,821+2,523 x_{1}+4,393 x_{2}+3,262 x_{4}+3,448 x_{6}\right)}
\end{aligned}
$$

Based on the Model Fitting Information obtained Sig for 0,000 means that the ordinal logistic regression model is suitable for use. Then it will be checked again whether each variable in the new model significantly affects the level of quality of health services. Using the Wald test the Empathy variable must be removed from the model. Furthermore, further testing will be carried out by eliminating the predictor variable Guarantee, Reliability and Empathy.

\section{Models without Predictor Variables Guarantee, Reliability and Empathy}

Analog obtained by the estimation model as follows:
1. $\widehat{Y}=\frac{1}{1+\exp \left(5,716+2,791 x_{1}+4,064 x_{2}+2,819 x_{4}\right)}$
2. $\widehat{Y}=\frac{1}{1+\exp \left(12,886+2,791 x_{1}+4,064 x_{2}+2,819 x_{4}\right)}$

Based on the Model Fitting Information obtained Sig for 0,000 means that the ordinal logistic regression model is suitable for use. Analog, then it will be checked again whether 
each variable in the new model significantly affects the level of quality of health services. Using the Wald test obtained no parameters to be excluded from the model.

\section{Selection of the Best Model}

The selection of the best model will be indicated based on the Deviance value. The best model criteria is the model with the smallest Deviance value. The following can be seen the Deviance value of Goodness-of-fit obtained as follows:

Table 1. Deviance value of Goodness of fit

\begin{tabular}{cc}
\hline Model & Deviance \\
\hline Overall Variables & 3,596 \\
Without Guarantee Variables & 6,147 \\
Without Guarantee Variables and Reliability & 2,536 \\
Without Guarantee Variables, Reliability and & 1,562 \\
Empathy & \\
\hline
\end{tabular}

In addition, from the Nagelkerke value obtained at 0.395 or $39.5 \%$. This means that predictor variables $\mathrm{X} \_1, \mathrm{X} \_2$ and $\mathrm{X} \_4$ can explain the $\mathrm{Y}$ response variable by $39.5 \%$ and the remaining $60.5 \%$ is explained by other variables.

\section{Conclusion}

Based on the description above it can be concluded model of the level of quality of public health services at Raden Mattaher Hospital uses Ordinal Logistic Regression as follows :

$$
\begin{gathered}
\widehat{Y}=\frac{1}{1+\exp \left(5,716+2,791 x_{1}+4,064 x_{2}+2,819 x_{4}\right)} \\
\widehat{Y}=\frac{1}{1+\exp \left(12,886+2,791 x_{1}+4,064 x_{2}+2,819 x_{4}\right)}
\end{gathered}
$$

Predictor variables that affect the level of quality of health services at Raden Mattaher Hospital are physical evidence, availability and completeness of facilities and responsive data.

\section{References}

[1] Agresti, A. (1990). Categorical Data Analysis. New York: John Wiley and Sons. Daniel, C.N dan Berinyuy. 2010. Using the Servqual Model to Assess Servis Quality and Customer Satisfaction, An Emprical Study of Grocery Stores in Umea. Umea University.

[2] Hosmer, D.W. and Lemeshow.(1989). Applied Logistic Regression. New York: Willey and Sons 
[3] Hosmer, D.W. and Lemeshow. (2000). Applied Logistic Regression. New York: Willey and Sons.

[4] Ihsanuddin. 2014. Kualitas Pelayanan Publik Pada Badan Perizinan Penanaman Modal Dan Promosi Daerah (BP2MPD) Kabupaten Indragiri Hilir. Jurnal Administrasi Publik dan Birokrasi Vol. 1 No. 2.

[5] Mulyadi, D., Uus. M. F dan Fitrani, C. 2013. Analisis Manajemen Mutu Pelayanan Kesehatan pada Rumah Sakit Karawang. Jurnal Manajemen vol.10. No.3

[6] Muninjaya,A.A.G. 2016. Revitalisasi Pelayanan Kesehatan Dasar (RPKD) Moenir. 1995. Manajemen Pelayanan Umum. Jakarta: Bumi Aksara.

[7] Nugroho, R. 2004. Kebijakan Publik Formulasi, Implementasi dan Evaluasi. Jakarta: Media Elex Komputindo.

[8] Tjiptono, F. 2001. Manajemen Jasa. Edisi Kedua. Yogyakarta : Andi Offset. Tjiptono, F \& Gregorius, C. 2011. Service, Quality and Satisfaction (ed 3). Yogyakarta: Andi Offset . 